УДК 342.92

DOI https://doi.org/10.32837/yuv.v0i1.1637

\title{
А. Бабінська,
}

аспірант кафедри адміністративного права

Київського національного університету імені Тараса Шевченка

\section{ШЛЯХИ ВДОСКОНАЛЕННЯ АДМІНІСТРАТИВНО-ПРАВОВИХ ЗАСАД КАДРОВОГО ЗАБЕЗПЕЧЕННЯ ОРГАНІВ ПРОКУРАТУРИ УКРАЇНИ}

Актуальність і необхідність удосконалення адміністративно-правових засад кадрового забезпечення органів прокуратури визначається сучасними викликами, що сформовані реформаційними процесами у суспільстві, політиці, правовій системі, ставленні до діяльності правоохоронних органів як пересічних осіб, так і міжнародних організацій. Так, наприклад, ще у 2012 році висловлювалась необхідність змінити процедуру добору кандидатів на посади прокурора та ретельно визначити цю процедуру на законодавчому рівні (думка щодо проекту закону про прокуратуру України, підготовлена Українською комісією 3 питань зміцнення демократії та верховенства права, прийнята Венеціанською комісією на своєму 92-му пленарному засіданні (Венеція, 12-13 жовтня 2012 р.), зокрема щодо:

- запровадження спеціальних правил відбору прокурорів;

- публічного розміщення інформації про вакансії та особливості добору на посади в органи прокуратури;

- проведення спеціальної перевірки доброчесності успішних кандидатів на посади прокурора;

- наявності окремих етапів проведення добору: письмовий анонімний тест, практичні завдання та співбесіда;

- недопуску кандидата, який здобув негативний результат спеціальної перевірки доброчесності до подальших процедур, виключення його зі списку потенційних кандидатів на прокурорську посаду;
- запровадження процедури права на призначення в іншу прокуратуру на підставі заяви, якщо це власне волевиявлення прокурора [1]. Під час аналізу чинного вітчизняного законодавства можна помітити, що деякі із цих положень знайшли своє втілення у нормах права, проте $€$ ще підстави для удосконалення адміністративно-правових засад кадрового забезпечення органів прокуратури. Адже високий рівень функціонування прокуратури залежить від кількісних та якісних показників іï кадрового складу, його мотивації, дисципліни, здатності і бажання до підвищення кваліфікації, ділових та морально-етичних якостей прокурорів.

Також варто звернути увагу на положення Стратегіi реформування судоустрою, судочинства та суміжних правових інститутів на 20152020 роки, схваленої Указом Президента України від 20 травня 2015 р. № $276 / 2015$ [2], де передбачено, що функціонування прокуратури та кримінальної юстиції як суміжних правових інститутів має свої недоліки, зокрема: недостатня структурна незалежність прокуратури в поєднанні з безкарністю та низьким рівнем підзвітності, невідповідність функцій прокуратури європейським стандартам; відсутність стратегічного планування, належного бюджетного і фінансового управління, низькі комунікаційні можливості; недостатній рівень функціональної незалежності та доброчесності прокурорів, потреба в більш розвинених інструмен- 
тах управління ефективністю, значно жорсткіших етичних вимогах і дисциплінарних правилах; непослідовне застосування процесуальних норм прокуратурою тощо. Наявність таких проблем прямо пов'язана зі станом кадрового забезпечення органів прокуратури.

Дослідження питань, пов'язаних із удосконаленням адміністративно-правових засад кадрового забезпечення органів прокуратури України, не $є$ новим для наукових пошуків. У різні часи відповідна сфера наукових інтересів була предметом уваги в роботах О. Агєєва, О. Анпілогова, В. Бабенко, М. Завального, С. Ківалова, М. Руденка, I. Сіліча, В. Середи, В. Шуби та ін. Проте вітчизняне законодавство, яке регулює особливості кадрового забезпечення органів прокуратури, є предметом поточного реформування і має свою специфіку та новації, що викликає необхідність оновленого наукового перегляду 3 урахуванням відповідних нормативно-правових змін.

Метою роботи є пошук шляхів удосконаленням адміністративно-правових засад кадрового забезпечення органів прокуратури України із урахуванням відповідних нормативно-правових змін на підставі аналізу наявних наукових, публіцистичних, нормативних джерел, правозастосовчої практики.

Слід зауважити, що спеціальне законодавство, зокрема Закон України «Про прокуратуру», не оперує поняттям «кадрове забезпечення», проте аналіз його норм дозволяє дійти висновку, що відповідні норми регулюють такий напрям кадрової політики. Так, слід звернути увагу на необхідність удосконалення окремих складових кадрового забезпечення органів прокуратури. Напрями такого вдосконалення можна умовно поділити на три групи.

1. Вдосконалення офіційного термінологічного ряду задля усунення суб'єктивного тлумачення та понятійної плутанини, зокрема закріплення в Законі України «Про прокуратуру» понять:
- прокурор - це посадова особа органів прокуратури, яка наділена державою особливим статусом щодо здійснення визначених Законом функцій, а також реалізацією спеціальних завдань у сфері правоохоронної діяльності;

- адміністративна посада - це визначена у ст. 39 Закону України «Про прокуратуру» та передбачена штатним розписом керівна посада в Oфici Генерального прокурора, обласних та окружних прокуратурах, а також у Спеціалізованій антикорупційній прокуратурі, на яку прокурор або інша особа призначаються у встановленому Законом порядку для виконання організаційно-розпорядчих та управлінських функцій.

- керівник - прокурор, який в установленому законом порядку призначений на адміністративну посаду та відповідно до службових повноважень і посадових обов'язків виконує управлінські та організаційно-розпорядчі функціі;

- прокурор вищого рівня - прокурор, який відповідно до системи органів прокуратури займає посаду у вищій ланці такої системи.

2. Вдосконалення переліку вимог до кандидатів на посаду прокурора. Якщо вже мова йде про реформаційні процеси, в тому числі і у сфері добору на посаду прокурора, то слід звернути на окремі аспекти.

Варто зауважити, що законодавством України визначаються окремі вимоги щодо високих морально-ділових якостей окремих посадових осіб, що займають посади в органах прокуратури, наприклад:

- «членами конкурсної комісіі повинні бути особи, які мають бездоганну ділову репутацию, високі професійні та моральні якості, суспільний авторитет, а також значний досвід діяльності у сфері запобігання або протидії корупції (ч. 2 ст. 8-1 Закону України «Про прокуратуру»);

- «конкурс має включати в себе оцінку професійного рівня, досвіду, морально-ділових якостей прокурора 
та перевірку його готовності до здійснення повноважень в іншому органі прокуратури, у тому числі вищого рівня» (ст. 38 Закону України «Про прокуратуру»);

- «під час вирішення питання щодо надання рекомендації для призначення на адміністративну посаду Рада прокурорів України враховує професійні та морально-ділові якості кандидата, а також його управлінсько-організаторські здібності та досвід роботи» (ч. 5 ст. 39 Закону України «Про прокуратуру»);

- «на посаду Генерального прокурора може бути призначений громадянин України, який: ... 3) має високі морально-ділові, професійні якості та організаторські здібності (ст. 39 Закону України «Про прокуратуру»).

Однак серед вимог до кандидатів на посаду прокурора взагалі положень про морально-ділові якості немає. А така ситуація може відкривати доступ до професії прокурора особам, які з огляду на особисті якості, наприклад наявні шкідливі звички, не зможуть належним чином виконувати професійні обов'язки. Тим паче, Кодекс професійної етики та поведінки прокурорів [3], який визначає основні принципи, моральні норми та правила прокурорської етики, якими повинні керуватися прокурори під час виконання своїх службових обов'язків та поза службою, вимагає від прокурорів високих морально-ділових якостей, а в разі систематичного (два і більше разів протягом одного року) або одноразового грубого порушення правил прокурорської етики прокурора може бути притягнуто до дисциплінарної відповідальності. Із цього приводу M.О. Ізотова зазначає: «Що стосується моральних якостей прокурорського працівника, то ці уявлення, напевно, грунтуються на загальноприйнятих нормах поведінки й моралі. У той же час, виходячи 3 вимог присяги, яку повинні складати особи, призначені на посаду вперше, можна виокремити додаткові моральні якості, які повинен мати про- курор. У зв’язку із цим передбачається, що прокурорські працівники повинні бути законослухняними, непримиренними до будь-яких порушень законів, активно захищати інтереси особистості, суспільства й держави, чуйно й уважно ставитися до пропозицій, заяв і скарг громадян, дотримуватися об’єктивності й справедливість під час вирішення долі людей, дорожити своєю професійною честю, бути зразком непідкупності, моральної чистоти, скромності, свято берегти і примножувати кращі традиції прокуратури» [4, с. 99]. Саме тому цілком слушним $€$ доповнення ст. 27 Закону України «Про прокуратуру» вимогою щодо високих морально-ділових якостей кандидата на посаду прокурора.

Також слід звернути увагу, що в окремих статтях Закону України «Про прокуратуру» важливе значення для призначення на посаду прокурора має наявність заборгованості зі сплати аліментів на утримання дитини. Наприклад: «Не може бути призначено прокурора на адміністративну посаду, якщо він має заборгованість зі сплати аліментів на утримання дитини, сукупний розмір якої перевищує суму відповідних платежів за шість місяців 3 дня пред'явлення виконавчого документа до примусового виконання» (ч. 6 ст. 39 Закону України «Про прокуратуру»); «На посаду Генерального прокурора може бути призначений громадянин України, який: ... не має заборгованості зі сплати аліментів на утримання дитини, сукупний розмір якої перевищує суму відповідних платежів за шість місяців з дня пред'явлення виконавчого документа до примусового виконання» (ч. 3 ст. 40 Закону України «Про прокуратуру»). У встановленому переліку документів, недохідних для подання для участі в доборі кандидатів на посаду прокурора $€$ «заява про відсутність заборгованості зі сплати аліментів на утримання дитини, сукупний розмір якої перевищує суму відповідних платежів за шість місяців з дня пред’явлення виконавчого доку- 
мента до примусового виконання» (ст. 30 Закону України «Про прокуратуру»). Окремо зазначено, що наявність заборгованості зі сплати аліментів на утримання дитини, сукупний розмір якої перевищує суму відповідних платежів за дванадцять місяців із дня пред'явлення виконавчого документа до примусового виконання, є підставою для звільнення прокурора з адміністративної посади Генеральним прокурором (ст. 41 Закону України «Про прокуратуру») та Генерального прокурора звільняється 3 адміністративної посади Президентом України за згодою Верховної Ради України (ст. 42 Закону України «Про прокуратуру»). Таким чином, як вбачається з положень законодавства, умова наявності заборгованості зі сплати аліментів на утримання дитини впливає на добір на посаду прокурора, впливає на проходження служби та є підставою для звільнення з адміністративної посади, у зв'язку із чим логічним видається доповнення ст. 27 Закону України «Про прокуратуру» вимогою щодо відсутності в кандидата на посаду прокурора заборгованості зі сплати аліментів на утримання дитини, сукупний розмір якої перевищує суму відповідних платежів за шість місяців з дня пред’явлення виконавчого документа до примусового виконання.

Аналізуючи окремі вимоги до кандидатів на посаду прокурора, вже зверталась увага на такі, як «вища юридична освіта» та «стаж роботи у сфері права». Зазначалося, що визначення на нормативному вищої юридичної освіти як «освіти, здобутої в Україні (або на території колишнього СРСР до 1 грудня 1991 року) за освітньо-кваліфікаційним рівнем спеціаліста або магістра, а також вища юридична освіта за відповідним освітньо-кваліфікаційним рівнем, здобута в іноземних державах та визнана в Україні в установленому законом порядку», все одно викликає певні запитання щодо переліку спеціальностей, які слід розглядати як підставу для здобуття вищої юридичної (а не будь-якої іншої) освіти. Прикла- дом належного нормативного зазначення такої вимоги можна вважати положення Порядку допуску до складення кваліфікаційного іспиту, порядку складення кваліфікаційного іспиту та методики оцінювання результатів складення кваліфікаційного іспиту для набуття права на заняття адвокатською діяльністю в Україні, затвердженого рішенням Ради адвокатів України від 17 грудня 2013 р. № 270 (зі змінами, внесеними Рішеннями Ради адвокатів України від 26 червня 2019 р. № 72) [5], зокрема: «Документ державного зразка (оригінал та нотаріально посвідчену копію) та додатки до нього, що підтверджують набуття заявником повної вищої юридичної освіти, не нижче ступеня магістра (спеціаліста) - другий (магістерський) рівень, спеціальність - «право», «правознавство», «правоохоронна діяльність», «міжнародне право». Таким чином, у вимогах визначено і ступінь і спеціальність здобутої освіти. У цьому контексті слід звернути увагу на положення Постанови Кабінету Міністрів України від 29 квітня 2015 р. № 266 «Про затвердження переліку галузей знань і спеціальностей, за якими здійснюється підготовка здобувачів вищої освіти» [6], де установлено, що особи, які здобули вищу освіту за спеціальностями «081 Право», «293 Міжнародне право» на першому (бакалаврському) i другому (магістерському) рівні вищої освіти і яким присуджено ступінь вищої освіти «магістр», можуть обіймати посади або провадити види діяльності, кваліфікаційні вимоги до яких передбачають наявність повної вищої або вищої юридичної освіти (з урахуванням змін від 01 лютого 2017 р. на підставі прийняття Кабінетом Міністрів України постанови № 53 «Про внесення змін до постанови Кабінету Міністрів України від 29 квітня 2015 р. № 266» [7]). Саме тому чітке визначення в Законі Украіни «Про прокуратуру» переліку спеціальностей, які можуть бути підставою для наявності у особи, що претендує на посаду прокурора вищої юридич- 


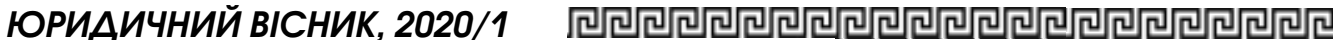

ної освіти, унеможливить виникнення додаткових проблемних запитань під час добору на посаду прокурора та поставить усіх кандидатів у рівне становище.

Щодо стажу роботи в галузі права, офіційно на рівні спеціального Закону визначено, що це «стаж роботи особи за спеціальністю після здобуття нею вищої юридичної освіти за освітньо-кваліфікаційним рівнем спеціаліста або магістра». Таке досить «загальне» визначення ускладнює розуміння сутності вказаного поняття та створює додаткові підстави для оскарження рішень під час вирішення питання про допуск у доборі на посаду прокурора.

В якості позитивного прикладу слід звернути увагу на Порядок допуску до складення кваліфікаційного іспиту, порядку складення кваліфікаційного іспиту та методики оцінювання результатів складення кваліфікаційного іспиту для набуття права на заняття адвокатською діяльністю в Україні, затверджений рішенням Ради адвокатів України від 17 грудня 2013 р. № 270 (зі змінами, внесеними Рішеннями Ради адвокатів України від 26 червня 2019 р. № 72), де зазначено, що до стажу роботи в галузі права слід зараховувати роботу на певних посадах і встановлено вичерпний перелік таких посад. Закріплення аналогічного переліку серед вимог до стажу у галузі права для кандидатів на посаду прокурора значно би спростило процедуру подання документів для участі в доборі, зробило би таку процедуру більш прозорою та зменшило би підстави для можливих оскаржень.

Окремо варто звернути увагу, що у вимогах до кандидатів на посаду прокурора зазначено, що «не може бути призначена на посаду прокурора особа, яка ... має захворювання, що перешкоджає виконанню обов'язків прокурора». Законодавством не передбачено, які саме захворювання можуть перешкоджати виконанню обов'язків прокурора (із акцентом саме на такий різновид професійної діяльності, а не будь-який інший). Таке нормативне формулю- вання вимагає наявності спеціального Переліку захворювань, що перешкоджають виконанню обов'язків прокурора, який повинен бути розроблений та затверджений спільно з Міністерством охорони здоров'я України.

Також, ураховуючи, що серед нормативних вимог до кандидатів на посаду прокурора відсутні вимоги щодо «прокурорського стажу», тобто перебування на посадах в органах прокуратури, в якості пропозиції слід внести можливість запровадження «інституту наставництва» за прикладом позитивного досвіду організації роботи прокуратури в Данії. Такий інститут передбачає обов'язкове закріплення за прокурорами, які вперше призначаються на посаду наставників 3 числа досвідчених прокурорів (за винятком керівників), які протягом трьох років надають практичну допомогу в освоєнні професіі прокурора, приділяють увагу формуванню i розвитку морально-етичних принципів. Це позитивно відобразиться на посиленні рівня особистих і ділових якостей вперше призначених прокурорів.

3. Вирішення процедурних проблем, що виникають під час проведення атестації прокурорів.

Атестація прокурорів наразі є досить актуальним питанням у реформаційних процедурах правоохоронної системи. Успішне проходження атестації діючими прокурорами є підставою для призначення на посаду прокурора і обов'язковою умовою для продовження служби в органах прокуратури. Однак із вересня 2019 року вже склалася певна практика проходження атестації прокурорами. Так, О.В. Баганець, коментуючи таку процедуру, висловив тези:

- «майже третина прокурорів ГПУ (197 осіб), які подали заяви, не пройшли перший етап переатестації здачу тестів на предмет володіння професійними знаннями»;

- «iз 1088 прокурорів центрального апарату ГПУ, які повинні були пройти так звану «переатестацію» на першому етапі, вже будуть звільнені 3 роботи 374 працівники, більшість із 
яких є професійно підготовленими прокурорами, здатними належним чином виконувати свої службові функції;

- «виникають питання із приводу якості і фаховості підготовлених для перевірки професійних знань прокурорів запитань у тестах, адже близько $70 \%$ із них взагалі не стосуються безпосередніх прокурорських функцій»;

- «виникають питання до рівня якості поставлених питань, тим більше відповідей на них саме для перевірки «професійної підготовки прокурорів», якщо до цього часу Генеральною прокуратурою так і не було оприлюднено для суспільства даних про те, хто саме 3 незалежних та авторитетних фахівців перевіряв ці тести і який висновок із цього було зроблено на предмет їх придатності для таких цілей»;

- «уже заподіяла істотної шкоди як проведенню досудового розслідування по великій кількості вчинених злочинів, так і здійсненню правосуддя. Зокрема, за даними 3MI, у Верховному Суді через переатестацію прокурорів були зняті з розгляду одразу 13 із 32 справ, запланованих на 24 жовтня 2019 р. Та й самі прокурори цього не приховують і стверджують, що у всіх органах прокуратури готуються або до тестів, або до звільнення 3 роботи, після чого багато 3 них збираються подавати позови до суду про поновлення на роботі» [8].

Також є прецеденти звільнення 3 посади прокурора через недотримання формальних вимог під час проходження атестації. Наприклад, для допуску до атестації потрібно було підписати заяву встановленого зразка. Цією типовою формою заяви визначено, що прокурор, який іiі подає, повинен погодитись із тим, що під час проведення співбесіди та ухвалення рішення кадровою комісією може братися до уваги інформація, отримана від фізичних та юридичних осіб (в тому числі анонімно), яка не підлягає додатковому офіційному підтвердженню. Заяви про переведення, які не відповідають цим вимогам, не приймаються.
Однак, на думку деяких прокурорів, така заява $€$ неприпустимою i написали їі у довільній формі. При цьому вони не заперечували проти додаткової перевірки професійної компетентності, професійної етики та доброчесності за наявності обгрунтованих підстав вважати їх невідповідними необхідному рівню прокурора Офісу Генерального прокурора чи відповідній адміністративній посаді. За невідповідність форми заяви було звільнено четверо працівників Генеральної прокуратури [9]. Тобто невідповідність заяви встановленій формі не стала підставою для відмови у прийнятті документів або повернення іх для усунення недоліків, а стала підставою для звільнення.

До того ж, слід зауважити, що Окружний адміністративний суд міста Києва відкрив провадження у справі за позовом до Генеральної прокуратури України щодо оскарження Порядку проходження прокурорами атестаціі [10]. Серед вимог позову - визнати протиправним та скасувати Наказ Генерального прокурора України № 221 від 03 жовтня 2019 р., яким було затверджено вищезгаданий порядок.

Зазначені положення свідчать про наявність проблем у механізмі проведення атестації прокурорів. Зокрема, до таких слід віднести: якість і фаховість підготовлених для перевірки професійних знань прокурорів запитань у тестах, інформацію про їх розробників; необхідність виконувати свої поточні обов'язки під час проходження атестації (що впливає і на якість роботи і на якість результатів атестаціi); застосування формальних вимог (наприклад, невідповідність заяви встановленій формі) для прийняття рішення про неуспішне проходження атестації. Тому варто оприлюднити інформацію про розробників тестів для проходження атестації прокурорами, а для забезпечення гласності та відкритості, посилення довіри до процедури під час проведення атестації доцільно запровадити онлайн-трансляцію співбесід 3 кандидатами. 


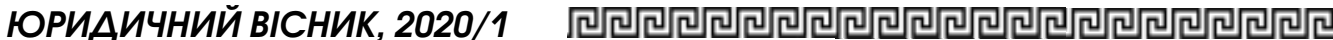

Таким чином, у цілому позитивно оцінюючи адміністративно-правове регулювання кадрового забезпечення органів прокуратури України, варто виокремити низку проблем, які виникають у цій сфері, та слід акцентувати увагу на необхідності вдосконалення окремих складових кадрового забезпечення органів прокуратури. Напрями такого вдосконалення можна умовно поділити на три групи: 1) вдосконалення офіційного термінологічного ряду задля усунення суб'єктивного тлумачення та понятійної плутанини, зокрема закріплення в Законі України «Про прокуратуру» окремих понять; 2) удосконалення переліку вимог до кандидатів на посаду прокурора; 3) вирішення процедурних проблем, що виникають під час проведення атестації прокурорів.

У статті з урахуванням реформ окремих елементів вітчизняної системи правоохоронних органів проведено системний правовий аналіз положень чинного законодавства та зроблено спробу пошуку шляхів удосконалення адміністративно-правових засад кадрового забезпечення органів прокуратури України. Доведено безпосередній взаємозв'язок між якістю кадрового забезпечення та належним рівнем виконання завдань прокуратури. Звернуто увагу на те, що актуальність і необхідність удосконалення адміністративно-правових засад кадрового забезпечення органів прокуратури визначається сучасними викликами, що сформовані реформаційними процесами у суспільстві, політиці, правовій системі, ставленні до діяльності правоохоронних органів як пересічних осіб, так $i$ міжнародних організаиій. В якості мети роботи визначено пошук шляхів удосконаленням адміністративно-правових засад кадрового забезпечення органів прокуратури України з урахуванням відповідних нормативно-правових змін на підставі аналізу наявних науко- вих, публіцистичних, нормативних джерел, правозастосовчої практики. у статті в цілому позитивно оцінено адміністративно-правове регулювання кадрового забезпечення органів прокуратури України, проте виокремлено низку проблем, які виникають у иій сфері, та акценттовано увагу на необхідності вдосконалення окремих складових частин кадрового забезпечення органів прокуратури. Напрями такого вдосконалення умовно поділено на три групи: 1) вдосконалення офіиійного термінологічного ряду задля усунення суб'єктивного тлумачення та понятійної плутанини, зокрема закріплення у Законі України «Про прокуратуру» окремих понять; 2) вдосконалення переліку вимог до кандидатів на посаду прокурора; 3) вирішення процедурних проблем, що виникають під час проведення атестації прокурорів. Наведені конкретні пропозиціі щодо вдосконалення адміністративно-правових засад кадрового забезпечення органів прокуратури України.

Ключові слова: прокурор, прокуратура, кадри, кадрове забезпечення, вимоги до кандидатів.

Babinska A. Ways to improve administrative and legal basis of human provision of bodies of the prosecutor's office of Ukraine

The study used the reform that was used in all domestic law enforcement systems that carried out systematic legal analysis, and analyzed the results of the study, which are verified through audits carried out by the administrative and legal framework of the personnel space of the prosecutor's office of Ukraine. It has been proved to influence one another, among which there is a personnel opening and the equal identification of the tasks of the prosecutor's office. Please note that it is up-to-date and credible that the administrative and legal principles of the personnel protection of the public 
prosecutor's office have been introduced, which were made by modern calls, which are systematized by the reform processes in the society, which consider Orthodox, consider it necessary for human rights organizations as translations, and international services. Only search employees are employed in their work, who have fulfilled the administrative and legal principles of personnel protection of the population of the Prosecutor's Office of Ukraine at the expense of such legislative and legal states that exist in modern scientific, journalistic, topical sources, law enforcers.

Leaving this positive assessment of the administrative and legal regulation of the personnel protection of the Prosecutor's Office of Ukraine, however, the null problem has been singled out, provided that information on the necessity of entering the office of the Prosecutor's Office personnel within the personnel space is required. The tense that is introduced by the conditions is divided into three groups: 1) improvement of the official terminological series in order to eliminate the subject of successful examination and understanding of the confusion recorded in the law of Ukraine "On the Prosecutor's Office" and to understand; 2) improving the review of the desired candidate for the position of prosecutor; 3) the decision on the problems, which are carried out during the attestation of the prosecutors. The concrete proposals on improvement of administrative and legal bases of personnel protection of the prosecutor's office of Ukraine are given.

Key words: prosecutor, prosecutor's office, personnel, staffing, requirements for candidates.

\section{Література}

1. Opinion on the Draft Law on the Public Prosecutor's Office of Ukraine (prepared by the Ukrainian Commission on Strengthening Democracy and the Rule of Law), adopted by the Venice Commission at its 92nd Plenary
Session (Venice, 12-13 October 2012). URL:https: / / wwr.venice.coe.int / webforms / documents $/$ ? pdf $=C D L-A D$ (2012)019-e.

2. Стратегія реформування судоустрою, судочинства та сумінних правових інститутів на 2015-2020 роки, схвалена Указом Президента України від 20.05.2015 p. № 276/2015. URL : https: / / zakon.rada.gov.ua/laws/show/ $276 / 2015$.

3. Кодекс професійної етики та поведінки прокурорів, затверджений Всеукраїнською конференцією прокурорів 27.04.2017 p. URL : https: / / zakon.rada.gov.ua / rada / show/ n0001900-17.

4. Ізотова М.О. Правовий статус керівника місиевої прокуратури : дис. ... канд. юрид. наук : 12.00.10. Харків, 2018. 216 с.

5. Порядок допуску до складення кваліфікаційного іспиту, порядок складення кваліфікаційного іспиту та методики оцінювання результатів складення кваліфікаційного іспиту для набуття права на заняття адвокатською діяльністю в Україні, затверджений рішенням Ради адвокатів України від 17.12.2013 р. № 270 (зі змінами, внесеними Рішеннями Ради адвокатів України від 26.06.2019 р. № 72). URL : https: / / kyiv.unba.org.ua/assets / uploads / новая\% 20nапка\% 201 / 2019-06-26-poryadki72_5d3ad2e33ccf6.pdf.

6. Про затвердження переліку галузей знань $і$ спеціальностей, за якими здійснюеться підготовка здобувачів вищої освіти: Постанова Кабінету Міністрів України від 29.04.2015 р. № 266. URL : https: / / zakon.rada.gov.ua/laws / show / ru/266-2015-n.

7. Про внесення змін до постанови Кабінету Міністрів України від 29 квітня 2015 р. № 266 : Постанова Кабінету Міністрів Украӥни від 01.02.2017 р. № 53. URL : https: / / zakon.rada.gov.ua/laws / show /53-2017-\% D0\% BF.

8. Баганець О. До чого може призвести така реформа прокуратури? URL : https: / / lexinform.com.ua/dumka-eksperta/ do-chogo-mozhe-pryzvesty-taka-reformaprokuratury/.

9. Граніт О. Атестація прокурорів дала mpiщuнy. URL : https://blog.liga.net/ user/ogranit/article/ 34843.

10. Оскарження порядку проходження прокурорами атестації - суд розгляне справу за правилами спрощеного провадження. Прес-служба Окружного адміністративного суду міста Києва. URL : http: / / oask.gov.ua/ node/4176. 